\title{
Az onkohematológiai betegségek kezelésében használt tirozinkináz-gátló imatinib és nilotinib csonthatásainak irodalmi áttekintése és a saját kutatási eredmények bemutatása
}

\author{
Kirschner Gyöngyi ${ }^{1^{*}}$ - Balla Bernadett dr. ${ }^{1^{*}}$ - Kósa János Pál dr. ${ }^{1}$ \\ Horváth Péter dr. ${ }^{1}$. Kövesdi Andrea ${ }^{1}$ \\ Lakatos Gergely dr. ${ }^{2}$ - Takács István dr. ${ }^{1}$ - Nagy Zsolt dr. ${ }^{1}$ \\ Tóbiás Bálint dr. ${ }^{1}$. Árvai Kristóf ${ }^{1}$. Lakatos Péter dr. ${ }^{1}$ \\ Semmelweis Egyetem, Általános Orvostudományi Kar, ${ }^{1}$ I. Belgyógyászati Klinika, \\ ${ }^{2}$ II. Belgyógyászati Klinika, Budapest
}

\begin{abstract}
A tirozinkináz-gátlók bizonyos onkohematológiai betegségek kezelésében elterjedten használt gyógyszerek. Több klinikai tanulmány igazolta, hogy a BCR-ABL specifikus tirozinkináz-gátlók alkalmazása komplex és még nem egyértelmúen azonosított módon változtatja meg a csontszövet élettani folyamatait. Mivel a kezelések egyre több beteget érintenek, illetve hosszú évtizedekig vagy akár élethosszig is tarthatnak, indokolt ezen mechanizmusok molekuláris hátterének részletesebb megismerése. A szerzők összefoglalják az imatinibbel és a nilotinibbel végzett, csontanyagcseréhez kapcsolódó alapkutatási eredményeket, humán klinikai megfigyeléseket, kiegészítve in vitro osteoblast-sejtkultúrákon végzett saját kísérleteik eredményeivel. Az összefoglalt kutatási eredmények alapján az imatinib és a nilotinib csontsejtekre gyakorolt hatása függ az alkalmazott hatóanyag-koncentrációtól, a sejtek érettségi állapotától, illetve az általuk kötött receptor-tirozinkináz útvonalak megoszlási arányától. Jelen közleményben elsőként készítettek a hazai szakirodalomban hiánypótló, átfogó irodalmi áttekintést a tirozinkináz-gátlók csontanyagcserét befolyásoló hatásaival kapcsolatban és végeztek teljes transzkriptom-analízist osteoblastokon a sejtszintú hatásmechanizmus jobb megértését szolgálva. Orv. Hetil., 2016, 157(36), 1429-1437.
\end{abstract}

Kulcsszavak: imatinib, nilotinib, osteoblast, osteoclast

Literature review and presentation of our own research results regarding the effects on bone of tyrosine kinase inhibitors imatinib and nilotinib used in the treatment of oncohematological diseases

\footnotetext{
Tyrosine kinase inhibitors are widely used for treatment of certain oncohematological diseases. Several clinical studies have confirmed that specific BCR-ABL tyrosine kinase inhibitors alter the physiological process of bone tissue in a complex and unclearly identified manner. Since these treatments are being given to more and more patients, and the therapy takes decades or lasts even lifelong, it is justifiable to obtain more detailed knowledge of the molecular background of these mechanisms. In this article the authors summarize preliminary research results and human clinical observations on imatinib and nilotinib which are related to bone metabolism, and present the results of their own experiments in in vitro osteoblast cultures. Based on the presented results, the effects of imatinib and nilotinib on bone cells depend on the concentration of imatinib and nilotinib, the maturation stage of the cells and the distribution ratio of receptor tyrosine kinase signaling pathways. In this study the authors firstly prepared a stop-gap, com-
}

*A szerzők egyenlő arányban vettek részt a kézirat megírásában. 
prehensive review in the Hungarian literature, regarding the effects of tyrosine kinase inhibitors on bone metabolism. In addition they firstly performed whole transcriptome analysis on osteoblasts in order to obtain a better understanding of the cellular molecular mechanisms.

Keywords: imatinib, nilotinib, osteoblast, osteoclast

Kirschner, Gy., Balla, B., Kósa, J. P., Horváth, P., Kövesdi, A., Lakatos, G., Takács, I., Nagy, Zs., Tóbiás, B., Árvai, K., Lakatos, $P$. [Literature review and presentation of our own research results regarding the effects on bone of tyrosine kinase inhibitors imatinib and nilotinib used in the treatment of oncohematological diseases]. Orv. Hetil., 2016, 157(36), 1429-1437.

(Beérkezett: 2016. május 23.; elfogadva: 2016. június 23.)

\begin{abstract}
Rövidítések
$\mathrm{BCR}-\mathrm{ABL}=$ breakpoint cluster region protein-Abelson murine leukemia viral onkogene homolog $1 ; \mathrm{BMD}=$ csontásványianyag-tartalom; c-fms = kolóniastimuláló faktor-1 receptor; c-kit = össejtfaktor-receptor; $\mathrm{CML}=$ krónikus myeloid leukaemia; $\mathrm{CSFlR}=$ kolóniastimulálófaktor-receptor; $\mathrm{CTX}-1=$ C-terminális kollagén keresztkötő 1; DDR1/DDR2 = diszkoidin domén receptor $1 / 2 ; \mathrm{GABA}=$ gamma-aminovajsav; GIST = gastrointestinalis stromatumor; $\mathrm{M}$-CSF $=$ makrofágkolóniastimuláló-faktor; OPG = oszteoprotegerin; PDGFR = thrombocytaeredetü növekedési faktor receptor; PDGFRA = thrombocytaeredetű növekedési faktor receptor alfa; PDGFRB = thrombocytaeredetű növekedési faktor receptor béta; RANKL $=$ receptoraktivátor nukleáris faktor $\kappa$ ligand; RT-PCR $=$ reverz transzkripció mediálta PCR-meghatározás; SCF = őssejtfaktor
\end{abstract}

A tirozinkináz-gátlók bizonyos onkohematológiai betegségek kezelésében elterjedten használt gyógyszerek. Az első tirozinkináz-gátló gyógyszerhatóanyag az imatinib volt, amelyet 2001-ben engedélyezett az Amerikai Gyógyszerügyi Hatóság (U.S. Food and Drug Administration - FDA) a krónikus myeloid leukaemiás (CML) betegek számára [1]. Azóta a világ egyre több országában egyre több beteg részesül imatinibterápiában. A CML-betegekben kimutatható BCR-ABL fúziós fehérje gátlására használt tirozinkináz-gátlók közül, a hazai és nemzetközi szakmai irányelvek alapján, a kezelések során először imatinibet (Glivec, 2001) alkalmaznak. Ha az imatinibkezeléssel nem érik el a beteg állapotának javulását (nincs remisszió, rezisztencia alakul ki vagy imatinibintolerancia lép fel), akkor a hatályban lévő eljárásrend alapján alkalmazható a nilotinib (Tasigna, 2007) vagy a dazatinib (Sprycel, 2006). Azoknál a betegeknél, akiknél sem az imatinibkezelés nem javasolt, és nilotinibre, valamint dazatinibre sem reagálnak megfelelően, alkalmazható a ponatinib (Iclusig, 2013) és a bozutinib (Bosulif, 2013) is.

A CML a fehérvérsejtek egy részét létrehozó csontvelő myeloid őssejtvonalát érinti. A betegséget a BCR-ABL génfúziót hordozó úgynevezett Philadelphia kromoszóma jellemzi, amelynek következtében túlzott mennyiségú kóros fehérvérsejt termelődik. A CML-betegségre jellemző Philadelphia kromoszóma a 22 -es és a 9-es kromoszóma reciprok transzlokációjával jön létre $\mathrm{t}(9 ; 22)$ (q34;q11). A 22-es kromoszóma hosszú karján kialakul a BCR-ABL onkogén, amiről egy hibás BCR-ABL fúziós fehérje íródik át. Ez a konstitutívan aktív tirozinkinázként múködő fehérje folyamatosan foszforilálja szubsztrátjait, amelyek sejtproliferációs, differenciációs kaszkádokat indítanak el. Ez a kontrollálatlan sejtosztódás az, ami a CML-sejtek folyamatos termelődését eredményezi.

$\mathrm{Az}$ imatinib a leukaemiás sejtek intracelluláris terébe speciális transzporterek segítségével jut, ezzel szemben a nilotinib esetén nem azonosították a pontos transzportmechanizmust, feltételezik, hogy a sejtbe jutás fóként passzív folyamatok révén valósul meg. A tirozinkináz-inhibitorok a CML-sejtekben - ATP kompetitív vegyületként - a BCR-ABL fehérje inaktív konformációjához kötődnek és gátolják annak aktivitását. Ezzel megakadályozzák a tumorsejtek proliferációját és azokban apoptózist indukálnak. Számos klinikai vizsgálat tanulmányozta a BCR-ABL specifikus tirozinkináz-gátlók biológiai hatásait, mint a farmakokinetikai és farmakodinamikai tulajdonságok, mellékhatásspektrum, különböző receptorokhoz való viszonyaik, illetve sejten belüli viselkedésük. A tanulmányok közül néhány igazolta, hogy ezek a hatóanyagok komplex módon befolyásolják többek között a csontanyagcsere-folyamatokat is (1. táblázat).

\section{Az imatinib és nilotinib csontsejtekre gyakorolt hatását vizsgáló in vitvo kísérleti eredmények irodalmi áttekintése}

Az imatinib és nilotinib csonthatása valószínúleg a csontsejtek fiziológiás receptorain keresztül valósul meg. Mindkét hatóanyag esetén ismertek a farmakológiai célponttól eltérő egyéb targetek, amelyekhez különböző affinitással képesek kapcsolódni. Ezek a PDGFRA, PDGFRB, c-kit, c-fms, M-CSF, DDR1, DDR2, CSF1R és SCF, amelyek közvetítésével a direkt csonthatás érvényesülhet. A tapasztalt hatás függ az alkalmazott hatóanyag-koncentrációtól, a sejtek érettségi állapotától, illetve az általa kötött receptor-tirozinkináz útvonalak megoszlási arányától [2-4]. 
1. táblázat |A vizsgált két tirozinkináz-gátló főbb tulajdonságainak és a csontanyagcserére való hatásainak összefoglalása

A nyilak a változások irányát jelölik. $\uparrow:$ Az adott tulajdonság vagy folyamat fokozódása, aktiválódása. $\downarrow$ : Az adott tulajdonság vagy folyamat csökkenése, gátlása.

\begin{tabular}{|c|c|c|}
\hline & \multicolumn{2}{|l|}{ Hatóanyag neve } \\
\hline & Imatinib & Nilotinib \\
\hline Gyógyszer (gyártó) & $\begin{array}{l}\text { Glivec/Gleevec } \\
\text { (Novartis) }\end{array}$ & Tasigna (Novartis) \\
\hline Terápiás javallat & $\begin{array}{l}\text { Gyermek és felnőtt } \\
\text { CML-betegek, } \\
\text { valamint felnőtt } \\
\text { GIST-betegek és } \\
\text { PDGFR } \\
\text { génátrendeződéssel } \\
\text { járó betegségek } \\
\text { kezelésére }\end{array}$ & $\begin{array}{l}\text { Felnőtt, krónikus } \\
\text { fázisú CML-betegek } \\
\text { kezelésére }\end{array}$ \\
\hline $\begin{array}{l}\text { Alkalmazott dózis } \\
\text { felnótteknél }\end{array}$ & $\begin{array}{l}400 \mathrm{mg} / \mathrm{nap}, \\
600 \mathrm{mg} / \mathrm{nap} \text { vagy } \\
2 \times 400 \mathrm{mg} / \text { nap }\end{array}$ & $\begin{array}{l}2 \times 300 \mathrm{mg} / \mathrm{nap} \\
\text { vagy } 1 \times 400 \mathrm{mg} / \\
\text { nap }\end{array}$ \\
\hline Hatóanyag, célpont & $\begin{array}{l}\text { BCR-ABL } \\
\text { onkoprotein, } \\
\text { tirozinkináz } \\
\text { aktivitásának gátlása }\end{array}$ & $\begin{array}{l}\text { BCR-ABL } \\
\text { onkoprotein, } \\
\text { tirozinkináz } \\
\text { aktivitásának gátlása }\end{array}$ \\
\hline $\begin{array}{l}\text { A célzott } \\
\text { farmakológiai } \\
\text { célponttól eltéró, } \\
\text { egyéb szubsztrátok }\end{array}$ & $\begin{array}{l}\text { KIT, SCF, DDR1, } \\
\text { DDR2, CSF1R, } \\
\text { PDGFR, c-fms, } \\
\text { karbonikus anhidráz } \\
\text { II }\end{array}$ & $\begin{array}{l}\text { PDGFR, KIT, } \\
\text { Efrin-receptor }\end{array}$ \\
\hline $\begin{array}{l}\text { Osteoblastsejtekre } \\
\text { gyakorolt hatás }\end{array}$ & $\begin{array}{l}\text { Proliferáció } \downarrow \text {, } \\
\text { differenciáció } \uparrow, \\
\text { sejtaktivitás } \uparrow, \\
\text { osteoblast-specifikus } \\
\text { génexpresszió } \uparrow\end{array}$ & $\begin{array}{l}\text { Proliferáció } \downarrow \text {, } \\
\text { differenciáció } \downarrow \text {, } \\
\text { OPG-expresszió és } \\
\text {-szekréció } \uparrow, \\
\text { RANKL-expresszió } \downarrow\end{array}$ \\
\hline $\begin{array}{l}\text { Osteoclastsejtekre } \\
\text { gyakorolt hatás }\end{array}$ & $\begin{array}{l}\text { Csontreszorpciós } \\
\text { sejtaktivitás } \downarrow \text {, } \\
\text { osteoclast- } \\
\text { prekurzorok } \\
\text { és érett osteoclastok } \\
\text { túlélése } \downarrow \text {, } \\
\text { differenciáció } \downarrow \text {, } \\
\text { aktivitás } \downarrow \text {, } \\
\text { osteoclastogenesis } \downarrow \text {, } \\
\text { sejtszám } \downarrow\end{array}$ & $\begin{array}{l}\text { Képződés } \downarrow \text {, } \\
\text { aktivitás } \downarrow \text {, } \\
\text { differenciáció } \downarrow \text {, } \\
\text { apoptózis } \uparrow, \\
\text { sejtszám } \downarrow\end{array}$ \\
\hline
\end{tabular}

Klinikai megfigyelések a csontanyagcsere vonatkozásában

Hypophosphataemia, hypokalcaemia,
hyperparathyreosis, csontspecifikus
szérummarkerek változása, megnövekedett
csontmineralizáció, szivacsos csontállomány
növekedése, a csont ásványianyag-
tartalmának növekedése

Az imatinib és nilotinib csontképző osteoblast- és csontbontó osteoclastsejtekre gyakorolt hatását immortalizált sejtvonalakon és rágcsálómodelleken tesztelték. $\mathrm{Az}$ in vitro kísérletek megfigyelései alapján az imatinib támogatja az osteoblastsejtek differenciációját $[2,5,6]$, azonban gátolja proliferációjukat és túlélésüket [5-10]. Emellett csökkenti az osteoclastogenesis és a csontreszorpció mértékét, valamint az osteoclast-prekurzorok és az érett osteoclastok túlélését [2, 6-9]. További tanulmányokban az imatinib hatására megnövekedett osteo- blast-specifikus génexpressziót, sejtaktivitást és mineralizációt tapasztaltak [2, 5-10].

Az imatinib dózisfüggő módon $(0,05-1 \mu \mathrm{M})$ indukálta a csontszövet képződését patkány-egér (MC3T3-El) osteoblast-sejtvonalakon. Mindezeket alkalikusfoszfatáz- (ALPL-), csontszialoprotein- (BSP-) és osteocalcin(BGLAP-) specifikus kvantitatív génexpressziós vizsgálatokkal is megerősítették. Az imatinib osteoblastproliferációt gátló hatását több modellben, így humán osteosarcoma-sejtvonalon (SaOS-2), valamint egér ST2 csontvelői stromasejt-kultúráján is leírták. Az imatinib közvetve vagy a csontbontósejt-előalakokra hatva közvetlenül is képes gátolni az osteoclastogenesist.

$\mathrm{Az}$ imatinibhez hasonlóan a nilotinib $(0,01-1 \mu \mathrm{M}$ koncentrációban) is gátolta az osteoblast-proliferációt. Azonban az osteoblast-differenciációt csökkentette vagy nem volt rá hatással. Az osteoblastsejtek nilotinibkezelése növelte az oszteoprotegerin (OPG) expresszióját és szekrécióját, valamint csökkentette a RANKL mRNSének átíródását [5]. Az osteoclastogenesist szintén hatékonyan gátolta.

\section{A két tirozinkináz-gátló csontanyagcserét érintő, humán klinikai megfigyeléseinek irodalmi összegzése}

Krónikus fázisú CML-betegek aspirációs csontvelőmintáin végzett microarray-vizsgálatok alapján az imatinib (400 mg/nap) a kezelés kezdeti időszakában nagymértékben befolyásolta a csontvelői haematopoeticus sejtek génexpressziós profilját. A bekövetkező transzkripciós változások szignifikánsan módosították a sejtciklust, a sejtnövekedést, a proliferációt, a DNS-replikációt és -rekombinációt, valamint a DNS-javító mechanizmusokat [3].

Magas dózisú imatinibterápia $(600 \mathrm{mg} / \mathrm{nap})$ során a betegek csontbiopszia-mintáinak mikrokomputer-tomográfiás feltárásánál igazolták, hogy osteopeniás CMLbetegeknél megnövekedett a csípő́csont szivacsos állománya [11]. Szivacsos csontállomány-növekedést 50 év feletti, osteoporoticus kezeltek esetén is tapasztaltak [9]. Ezzel szemben több, terápia alatt álló betegnél mérték a csontásványianyag-tartalom csökkenését a combnyak területén. A csontmarkerek szérumszintjének vizsgálatai alapján a csontbontó osteoclastsejtek számának és aktivitásának csökkenését figyelték meg. Jelentős csökkenést figyeltek meg például a szérum-CTX-1 mennyiségében, ami csökkent osteoclast-aktivitásra utal $[5,11]$. De ezt a csökkenést a csontépítő osteoblastsejtek aktivitása nem követte és az erre vonatkozó klinikai megfigyelések egymásnak ellentmondóak voltak [11-14]. A tirozinkinázgátlókkal kezelt betegeknél hypophosphataemia $[5,9$, $12,13,15,16]$, hypocalcaemia $[12,13,15,16]$, valamint hyperparathyreosis $[12,13,15,16]$ lépett fel.

Kezdetben számos kutatócsoport jutott olyan eredményre, hogy az onkohematológiai betegségek kezelé- 
sében használt tirozinkináz-gátlók, mint például az imatinib és a nilotinib, pozitív csontanyagcsere-változásokat idézhetnek elő. A későbbi kiterjedtebb vizsgálatok azonban már nem minden esetben erösítették meg ezeket a megfigyeléseket. Sőt arról is beszámoltak, hogy imatinib hatására az osteoblastok aktivitását jelző szérumoszteokalcin-szint [11-13, 17], valamint a BMD egyaránt csökken.

Napjainkban már elmondható, hogy a tirozinkinázgátlóknak nincs egyértelmú pozitív hatása a csontanyagcserére. Azonban az osteoblast- és osteoclastsejtek müködésének befolyásolásán keresztül komplex módon változtatják meg a csontszövet élettani folyamatait. Mivel a kezelések egyre több beteget érintenek, illetve hoszszú évtizedekig vagy akár élethosszig is tarthatnak, indokolt ezen mechanizmusok molekuláris hátterének jobb megismerése. Ezért a saját kutatásunk célja az volt, hogy megvizsgáljuk az imatinib és nilotinib osteoblastsejtekre kifejtett hatásait a teljes transzkriptom szintjén, valamint, hogy feltérképezzük a kezelés hatására a sejten belül megváltozott számos jelátviteli és szabályozó útvonalat.

\section{Saját kutatási eredmények bemutatása}

\section{Anyagok és módszerek}

\section{In vitro sejtkultúra}

Tanulmányunk során in vitro vizsgálatokat végeztünk imatinibbel és nilotinibbel kezelt egérpraeosteoblastsejtkultúrán. Az MC3T3-El sejteket az ATCC-től (American Type Culture Collection) (Rockville, MD, Amerikai Egyesült Államok) vásároltuk. A sejteket Minimum Essential Medium Eagle Alpha Modification ( $\alpha$-MEM; Sigma, St. Louis, MO, Amerikai Egyesült Államok) sejttenyésztő médiumban tartottuk, kiegészítve $0,292 \mathrm{~g} / \mathrm{L}$ L-glutaminnal (Sigma), 5\% magzatiborjúszérummal (FCS; Sigma), valamint 1\% antibiotikummal (penicillin, streptomicin-szulfát és amphotericin B; Sigma). A sejteket $37{ }^{\circ} \mathrm{C}$-on, $5 \% \mathrm{CO}_{2}$ és $78 \%$ páratartalom mellett tenyésztettük. A sejtek átoltása 70\%-os konfluencia esetén történt. Az átoltások során 0,25\% Trypsin EDTA-oldatot (Sigma) használtunk. A kísérleteket a sejtkultúrákkal 8-15 átoltás között végeztük el.

\section{In vitro kezelés imatinibbel és nilotinibbel - sejtélet- képesség-mérés}

A vizsgálatokhoz három csoportot alakítottunk ki: imatinibbel kezelt csoportot, nilotinibbel kezelt csoportot és egy kezeletlen kontrollcsoportot. A megfelelő kezelési idő és dózis megválasztása érdekében először különböző imatinib (Glivec/Gleevec, STI571, CGP 57148B; Novartis, Svájc) és nilotinib (Tasigna; Novartis, Svájc) koncentrációt $(30 \mathrm{nM}-20 \mu \mathrm{M})$ alkalmazva vizsgáltuk a sejtek túlélését. A kísérletek során igyekeztünk az in vitro kultúrák esetén elérhető leghosszabb kezelést alkalmazni (1-6 nap). A sejtéletképesség méréséhez a tápoldat eltávolítása után $100 \mu \mathrm{l} /$ lyuk triklór-ecetsavval
(Sigma) fixáltuk a sejteket, majd $100 \mu \mathrm{l}$ 4\%-os Sulforhodamine-B (SRB, Sigma) oldattal megfestettük 1\%-os ecetsavas közegben. A felesleges festékoldat eltávolítása után a sejttenyésztő lemezeket négyszer átöblítettük 1\%os ecetsavoldattal, ezt követően szobahőmérsékleten hagytuk megszáradni. A kötött SRB-t $100 \mu 10$ mM-os Trisma-oldatban (Sigma) feloldottuk és a sejttenyésztő lemezeket 5 percig rázattuk. A méréseket Multiskan Spectrum V1.2 1500-636 készülékkel (Thermo Fisher Scientific Inc., Waltham, MA, Amerikai Egyesült Államok) 520 nm-en, 96 lyukú Thermo Cliniplateken (Thermo Fisher Scientific Inc.) végeztük. Az eredmények alapján meghatároztuk a megfelelő inkubálási időt és hatóanyag-koncentrációt. A tirozinkináz-gátlókkal kezelt sejteket 24 lyukú sejttenyésztő lemezen $1 \mu \mathrm{M}$-os hatóanyag-koncentráció mellett 6 napig inkubáltuk. Minden esetben 3 párhuzamos mérést végeztünk.

\section{RNS-izolálás}

A kezelt és kezeletlen osteoblastsejtekból az RNS-izolálást High Pure Total RNA Isolation System (Roche, Indianapolis, IN, Amerikai Egyesült Államok) segítségével hajtottuk végre, a gyártó elő́rása szerint. Az izolált RNS

2. táblázat $\mid$ Az imatinibkezelt sejtekben azonosított top kanonikus útvonalak

\begin{tabular}{|c|c|c|c|}
\hline $\begin{array}{l}\text { Kanonikus } \\
\text { útvonalak }\end{array}$ & -log $(\mathrm{p} \text {-érték })^{\mathrm{a}}$ & Arány ${ }^{\mathrm{b}}$ & $\begin{array}{l}\text { Génszimbólumok } \\
(\operatorname{logFC} \text {-érték) }\end{array}$ \\
\hline $\begin{array}{l}\text { Reelin jelátviteli } \\
\text { útvonal }\end{array}$ & $2,61 \mathrm{E} 00$ & 7,59E-02 & $\begin{array}{l}\text { MAP3K9 }(3,41), \\
\text { MAPK8IP2 } \\
(2,10), \\
I T G A 2(2,35), \\
D A B 1(2,24), \\
\operatorname{RELN}(3,71), \\
\operatorname{DCX}(1,86)\end{array}$ \\
\hline $\begin{array}{l}\text { Zsírsavaktiváló } \\
\text { jelátviteli útvonal }\end{array}$ & $1,69 \mathrm{E} 00$ & $1,54 \mathrm{E}-01$ & $\begin{array}{l}A C S L 6(3,39), \\
A C S B G 2(2,42)\end{array}$ \\
\hline $\begin{array}{l}\text { GABA-receptor } \\
\text { jelátviteli útvonal }\end{array}$ & $1,63 \mathrm{E} 00$ & $6,35 \mathrm{E}-02$ & $\begin{array}{l}\text { GABRQ }(2,69), \\
\text { GABRG3 }(1,95), \\
\text { GABBR2 }(2,74), \\
\text { ADCr1 }(3,16)\end{array}$ \\
\hline $\begin{array}{l}\text { Szertoli-szertoli } \\
\text { sejtinterakciós } \\
\text { jelátviteli útvonal }\end{array}$ & $1,52 \mathrm{E} 00$ & $4,07 \mathrm{E}-02$ & $\begin{array}{l}\text { CLDN10 }(1,94), \\
\text { MAP3K9 }(3,41), \\
\text { EPB41 }(2,51), \\
\text { CTNNA2 }(2,76), \\
\text { CLDN4 }(2,21), \\
\text { ITGA2 }(2,35), \\
\text { Gucylb2 }(2,86)\end{array}$ \\
\hline $\begin{array}{l}\gamma \text {-linolénsav- } \\
\text { bioszintézis }\end{array}$ & $1,52 \mathrm{E} 00$ & $1,25 \mathrm{E}-01$ & $\begin{array}{l}A C S L 6(3,39), \\
A C S B G 2(2,42)\end{array}$ \\
\hline $\begin{array}{l}\text { Szerotoninreceptor } \\
\text { jelátviteli útvonal }\end{array}$ & $1,5 \mathrm{E} 00$ & $7,5 \mathrm{E}-02$ & $\begin{array}{l}\operatorname{HTR} 5 A(2,06), \\
\operatorname{ADC} 1(1,45), \\
\operatorname{HTR} 1 A(2,88)\end{array}$ \\
\hline
\end{tabular}

${ }^{\mathrm{a} A}$ - $\log (\mathrm{p}$-érték) számításához Fisher egzakt tesztet használtunk.

'Az arány kiszámításakor a saját kísérleti eredményeink alapján az adott útvonalhoz hozzárendelhető gének számát elosztottuk az IPA adatbázisa alapján az útvonalhoz tartozó összes génnel.

'Az adott útvonalakhoz rendelt, a kezelés hatására szignifikáns expressziós eltérést mutató gének és azok logFC-értékei. 
minőségét Bioanalyzeren (Agilent Technologies, Santa Clara, CA, Amerikai Egyesült Államok), mennyiségét Qubit fluorométeren (Life Technologies, Carlsbad, CA, Amerikai Egyesült Államok) ellenőriztük. Ezt követően a párhuzamos biológiai minták poolozása után a teljes transzkriptómaanalízis kivitelezését Applied Biosystems SOLiD ${ }^{\mathrm{TM}}$ V4 készüléken (Life Technologies) végeztük el.

\section{SOLiD új generációs RNS-szekvenálás}

A tisztított, DNS-mentesített totál RNS-molekulák ( $>5 \mathrm{mg} / \mathrm{minta}, \mathrm{RIN}>8,0, \mathrm{cc}>400 \mathrm{ng} / \mathrm{ml}$ ) teljes transzkriptomanalízisét új generációs $50+20$ bp reads pairedend technológiával a SeqOmics Biotechnológiai Kft. (SeqOmics Biotechnológiai Kft., Szeged, Magyarország; http://www.seqomics.hu/) végezte.

\section{Statisztikai analízis}

Mindkét hatóanyag esetében az expresszálódott gének logFC (fold-change: az expressziós változás mértéke a kezelt csoportban a kontrollcsoporthoz viszonyítva) értékei alapján meghatároztuk a szignifikáns változást mutató géneket Benjamini and Hochberg False Discovery Rate számítás segítségével. A szignifikanciaszint 0,05 volt. A kiválasztott szignifikáns géneket Ingenuity Pathway Analysis (IPA) (QIAGEN, Redwood City, CA, Amerikai Egyesült Államok; www.ingenuity.com) szoftver segítségével értékeltük ki. Kiemelt figyelmet fordítottunk a kísérletbe bevont hatóanyagok csontanyagcserére gyakorolt hatásának vizsgálatára.

\section{Eredmények}

\section{Szignifikáns gének azonositása}

Az imatinibbel kezelt osteoblastsejtekben 16,383, a nilotinibbel kezelt csoportban 16,951, a kezeletlen, kontrollsejtekben pedig 17,290-féle annotált RNS-t azonosítottunk.

Az imatinib esetén 358, míg a nilotinibkezelést követően 21 szignifikánsan eltérő expressziós mintázatot mutató gént találtunk a kontrollsejtekhez képest. A két kezelt csoport között három gén (AI593442, Gm11225, ZFP184) egyezett meg, közel azonos expressziós aktivitással. Az azonosított szignifikáns gének imatinib esetén mind upregulálódtak, nilotinib esetén egy kivételével szintén mind overexpresszálódtak a logFC-értékek alapján.

\section{Azonosított jelátviteli útvonalak}

Mindkét hatóanyag esetén a szignifikáns expressziós különbséget mutató géneket jelátviteli útvonalakba rendeztük Ingenuity Pathway Analysis segítségével. Az azonosított top jelátviteli útvonalak többsége különbözik a két hatóanyagnál. Az imatinibbel végzett kísérletek alapján 6 , a nilotinib esetén pedig 5 top jelátviteli útvonalat azonosítottunk (2. és 3. táblázat). A GABA-(gamma-aminovajsav-) receptor jelátviteli útvonal volt az egyedüli,
3. táblázat |A nilotinibkezelt sejtekben azonosított top kanonikus útvonalak

\begin{tabular}{|c|c|c|c|}
\hline Kanonikus útvonalak & -log $(\mathrm{p} \text {-érték })^{\mathrm{a}}$ & Arány ${ }^{\mathrm{b}}$ & $\begin{array}{l}\text { Génszimbólumok } \\
\text { (logFC-érték) }^{c}\end{array}$ \\
\hline $\begin{array}{l}\text { EIF2 jelátviteli } \\
\text { útvonal }\end{array}$ & $5,27 \mathrm{E} 00$ & $2,37 \mathrm{E}-02$ & $\begin{array}{l}R P L 17(2,41), \\
R P L 39(1,99), \\
R P S 23(3,45)\end{array}$ \\
\hline $\begin{array}{l}\text { Embrionális } \\
\text { őssejt-differenciáció } \\
\text { szívsejtvonal irányba }\end{array}$ & $2,14 \mathrm{E} 00$ & $1 \mathrm{E}-01$ & NANOG $(2,06)$ \\
\hline $\begin{array}{l}\text { Az embrionális } \\
\text { őssejtek } \\
\text { transzkripciót } \\
\text { szabályozó hálózata }\end{array}$ & $1,56 \mathrm{E} 00$ & $2,63 \mathrm{E}-02$ & $N A N O G(2,06)$ \\
\hline $\begin{array}{l}\text { Oct } 4 \text { szerepe az } \\
\text { emlős embrionális } \\
\text { őssejt } \\
\text { pluripotenciában }\end{array}$ & $1,49 \mathrm{E} 00$ & $2,22 \mathrm{E}-02$ & NANOG $(2,06)$ \\
\hline $\begin{array}{l}\text { GABA-receptor } \\
\text { jelátviteli útvonal }\end{array}$ & $1,34 \mathrm{E} 00$ & $1,59 \mathrm{E}-02$ & $G A B R B I(2,83)$ \\
\hline
\end{tabular}

${ }^{\mathrm{a} A}$ - $\log$ (p-érték) számításához Fisher egzakt tesztet használtunk.

${ }^{\mathrm{b}} \mathrm{Az}$ arány kiszámításakor a saját kísérleti eredményeink alapján az adott útvonalhoz hozzárendelhető gének számát elosztottuk az IPA adatbázisa alapján az útvonalhoz tartozó összes génnel.

'Az adott útvonalakhoz rendelt, a kezelés hatására szignifikáns expressziós eltérést mutató gének és azok logFC-értékei.

amely mindkét hatóanyag esetén a top kanonikus útvonalak között szerepelt. Eredményeinkben három ioncsatorna ( $G A B R Q, G A B R B I$ és GABRG3), egy G-proteinkapcsolt receptor $\mathrm{B}(G A B B R 2)$ és az l-es típusú adenilát-ciklázt kódoló gén $(A D C \Upsilon 1)$ kapcsolódott ehhez az útvonalhoz.

$\mathrm{Az}$ imatinibkezelés hatására az osteoblastsejtekben a legmarkánsabb változást a reelin jelátviteli útvonal érte el, amely a kaszkádhoz rendelhető összesen 6 génnel képviseli magát. A lipidmetabolizmusban szerepet játszó két útvonal (zsirsav-aktivációs hálózat és $\gamma$-linolénsavbioszintézis) is jelentős különbséget mutatott. A szertoliszertoli sejtinterakciós jelátviteli útvonal szerepét elsősorban a here sejtjeinek növekedésében, proliferációjában és fejlődésében írták le. Kísérleteinkben az útvonalhoz 7 szignifikánsan upregulálódott gén csoportosítható. A szerotoninreceptor jelátviteli útvonalról igazolták, hogy erôs pozitív hatása van a csonttömegre. A vizsgálatunkban ez az útvonal 3 génnel képviselteti magát. Annak ellenére, hogy az azonosított kanonikus útvonalakhoz tartozó p-értékek jelentősen meghaladják a szignifikancia küszöbértékét ( $\mathrm{p} \leq 0,05)$, a szoftver nem tudta megjósolni az útvonalak aktivitási mintázatát.

A nilotinibbel kezelt sejtek teljes transzkriptomanalízise során azonosított öt top kanonikus útvonal közül az EIF2 jelátviteli útvonal volt a legszignifikánsabb, 3 hozzá kapcsolható génnel. Az EIF2 (eukaryotainiciációs faktor 2) -komplexnek fontos szerepe van a transzláció folyamatának elindításában. A további szabályozási útvonalakat egy kritikus homeobox gén képviseli, a NANOG, 
amely a sejtek önmegújulási és dedifferenciálódási folyamataiban szerepet játszó transzkripciós faktort kódol.

\section{Azonosított top upstream regulátorok}

Öt-öt úgynevezett top upstream regulátort azonosítottunk, mind az imatinibbel, mind a nilotinibbel kezelt osteoblastok teljes mRNS-szekvenálása során. Az elemzésben statisztikailag szignifikánsnak a $\mathrm{p}<0,01$ értéket tekintettük, Fisher egzakt tesztet alkalmazva. Ezek a felsőbb szintû́ transzkripciós szabályozóelemek magyarázatot adhatnak a megfigyelt génexpressziós változásokra. Az imatinib esetén ezek a következők voltak: GLDN, FREM2, NRCAM, GRIPI és VLDLR. A nilotinibcsoportban: FAAH, MARCH7, ACVRIB, RAD23B és $A C V R I C . \mathrm{Az}$ azonosított upstream regulátorok közül több esetében is ismertek adatok a csontanyagcserével összefüggésben. A megtalált upstream szabályozóelemeket kódoló gének összefoglalása és azok csontanyagcseréhez köthető biológiai funkcióinak áttekintése megtalálható a 4. és 5. táblázatban [18-25].

\section{Megbeszélés}

Munkánkban megvizsgáltuk az onkohematológiai betegségek terápiájában használt tirozinkináz-gátló imatinib és a nilotinib vegyületek hatását a teljes transzkriptom szintjén in vitro egérosteoblast-sejtkultúrában. Ez volt az első olyan vizsgálat, ahol a csontképzésben szerepet játszó osteoblastok teljes mRNS-készletét és annak a kezelés hatására bekövetkezett expressziós változását analizálták. Korábbi tanulmányokban már megjelentek adatok tirozinkináz-inhibitorok alkalmazását követően, a csontszövet legjellemzőbb markereinek génkifejeződésére fókuszálva. Azonban komplex, sejtszintú transzkripciós mintázatbeli elemzés a csontanyagcsere vonatkozásában ez idáig nem történt. Mindkét hatóanyag esetében meghatároztuk a szignifikáns expressziós különbségeket mutató géneket, azonosítottuk a top jelátviteli rendszereket és az upstream regulátor géneket, útvonal-analízisek segítségével. Kiemelt figyelmet fordítottunk a hatóanyagok feltételezett csontanyagcsere-modifikáló hatásainak értelmezésére és magyarázatára. Mivel a tirozinkináz-gátlókkal végzett terápia általában évtizedekig vagy akár élethosszig is tarthat, ezért az imatinib- és nilotinibkezelések (6 napos inkubációs idő) hosszabb távú hatását igyekeztünk vizsgálni in vitro sejtes rendszerben. Így a bemutatott eredmények elsősorban nem a gyors, hanem a lassabban kialakuló másodlagos génaktivitásokban bekövetkező változásokat tükrözik.

Több klinikai tanulmány is igazolta, hogy ezek a tirozinkináz-gátló vegyületek alkalmazásuk során komplex módon változtatják meg a csont homeosztatikus folyamatait. A publikált eredmények sokszor egymásnak ellentmondóak, amit magyarázhat a vizsgált sejtek eltéró érettségi állapota [2], az alkalmazott hatóanyagok koncentrációja $[2,5]$, azok kémiai tulajdonságai, illetve kináztarget-spektruma. Saját eredményeink is bizonyítják,
4. táblázat $\mid A z$ imatinibkezelt sejtekben azonosított upstream regulátorok

\begin{tabular}{|c|c|}
\hline Génszimbólum és -név & $\begin{array}{l}\text { Általános biológiai funkció és a csontanyagcsere } \\
\text { szabályozásában betöltött szerep }\end{array}$ \\
\hline $\begin{array}{l}\text { FREM2 } \\
\text { FRAS1-related } \\
\text { extracellular matrix } \\
\text { protein } 2\end{array}$ & $\begin{array}{l}\text { Extracelluláris mátrixprotein, szükséges a } \\
\text { hám integritásának fenntartásához és az } \\
\text { epidermalis adhézióhoz. } \\
\text { Közvetett módon részt vehet a csont élettani } \\
\text { folyamatainak regulálásában. Mivel } \\
\text { kapcsolatban áll olyan molekulákkal, } \\
\text { amelyek például az oszteokalcin- } \\
\text { génexpresszió szabályozásában vesznek részt } \\
(M D M 2) \text { [18], a csonttörés gyógyulását } \\
\text { támogatják (EGFL6) [19], az osteoblast- } \\
\text { differenciációt serkentik (NPNT) [20]. }\end{array}$ \\
\hline $\begin{array}{l}\text { GLDN } \\
\text { Gliomedin }\end{array}$ & $\begin{array}{l}\text { Ranvier-befüződések kialakulásában vesz } \\
\text { részt a myelinhüvelyes axon mentén. }\end{array}$ \\
\hline $\begin{array}{l}\text { GRIPI } \\
\text { Glutamate receptor } \\
\text { interacting protein } 1\end{array}$ & $\begin{array}{l}\text { Az általa kódolt protein elsősorban az } \\
\text { idegsejtekben transzportfolyamatokban vesz } \\
\text { részt. Jelet közvetít a citoszkeletális és } \\
\text { membránfehérjék között. } \\
\text { Interakcióba lép számos, a csonttömeg } \\
\text { növekedését befolyásoló molekulával } \\
\text { (NRII3, MEF2C, ESRI) [21-23], valamint } \\
\text { az osteoblastok differenciációját befolyásoló } \\
\text { ösztrogénszerú receptor-alfával is ( } E S R R A \text {, } \\
\text { estrogen related receptor alpha). }\end{array}$ \\
\hline
\end{tabular}

\begin{tabular}{ll}
\hline NRCAM & $\begin{array}{l}\text { Az immunoglobulin-szupercsalád tagja. } \\
\text { A geuronal cell } \\
\text { adhesion molecule }\end{array}$ \\
& $\begin{array}{l}\text { vesz a neuron-neuron sejtadhézióban, } \\
\text { továbbá a Ranvier-befüződések } \\
\text { kialakulásának molekuláris folyamataiban. }\end{array}$ \\
\hline VLDLR & $\begin{array}{l}\text { Lipoproteinreceptor, amelynek szubsztrátja } \\
\text { Very low density }\end{array}$ \\
lipoprotein receptor & $\begin{array}{l}\text { lipoproteinmolekula. Hozzákapcsolódva, } \\
\text { endocitózissal a sejt belsejébe juttatja azt. }\end{array}$ \\
& $\begin{array}{l}\text { Szerepet játszik a VLDL-triglicerid } \\
\text { metabolizmusban és a reelin jelátviteli } \\
\text { útvonalban is. }\end{array}$ \\
& A koleszterinszint szabályozásán keresztül \\
hathat a BMD-re és a csontok megfeleló \\
mechanikai tulajdonságainak megtartására. \\
Az osteoblast-proliferációt serkenti.
\end{tabular}

A gének neveit és általános biológiai szerepük leírását a GeneCards (http:// www.genecards.org), NCBI (http://www.ncbi.nlm.nih.gov/gene) és az IPA (https://reports.ingenuity.com) adatbázisaiból gyüjtöttük. Az upstream regulátorok által szabályozott elemek listáját az IPA-elemzés eredményei adták. A csontanyagcseréhez köthető biológiai szerepüket a felsorolt adatbázisokból és a szakirodalomból gyújtöttük.

hogy a két inhibitor eltérő módon hat az osteoblastsejtek génkifejeződési mintázatára. Ismert, hogy az imatinib a BCR-ABL célmolekulája mellett több sejtfelszíni tirozinkináz-receptorhoz is képes kapcsolódni, míg a nilotinib jóval specifikusabb, a tirozinkináz-receptorok többségével nem kötődik. A statisztikailag szignifikáns különbséget mutató gének között csak 3 közös volt (ZFP184, Gm11225, AI593442) a két kezelt csoportban. A ZFP184 (Zinc finger protein 184), amely transzkripciót szabályozó folyamatokban vesz részt, és a CLICI (chloride intracellular channel 1) kapcsolatán keresztül 
5. táblázat |A nilotinibkezelt sejtekben azonosított upstream regulátorok

\begin{tabular}{ll}
\hline Génszimbólum és -név & $\begin{array}{l}\text { Általános biológiai funkció és a csontanyagcsere } \\
\text { szabályozásában betöltött szerep }\end{array}$ \\
\hline$A C V R 1 B$ & Transzmembránreceptor. Az l-es típusú \\
Activin receptor & aktivinreceptor komplexet képez a 2-es \\
type-1B & típussal, és az így kialakuló komplex \\
& szabályozza például az idegsejt- \\
& differenciációt és -túlélést, \\
& szőrtüszófejlődést, FSH-termelést, \\
& sérülésgyógyulást, extracelluláris mátrix \\
& termelődését, immunszuppressziót és \\
& karcinogenezist. \\
& Az $A C V R 1 B$ az aktivinútvonal részeként \\
& szerepet játszik a csontvázrendszer \\
& fejlődésében. Aktivinrendszer szabályozza \\
& a csontsejt-differenciációt és -proliferációt \\
& {$[24]$.}
\end{tabular}

\begin{tabular}{ll}
\hline ACVR IC & Az aktivin AB, aktivin B és a NODAL \\
Activin receptor & receptora. Részt vesz a sejtdifferenciációban, \\
type-1C & növekedésgátlásban és az apoptózisban. \\
& A csontfejlődésben és a remodeling során \\
& fontos molekulákat szabályoz \\
& (például: ephrinB2, CASP3, SMAD3).
\end{tabular}

$F A A H$

Fatty acid amide hydrolase

$M A R C H 7$

Az általa kódolt integrális membránfehérje a zsírsavamidok hidrolíziséért felelős.

A múködése során keletkező zsírsavamidok hatással vannak az osteoblastokra és az osteoclastokra, stimulálják a csontépítést és gátolják a reszorpciót [25].

E3 ubiquitinligázok ring finger típusa.

Membrane-associated Ideiglenesen megköti a célfehérjét és ring finger (C3HC4) ubiquitint kapcsol hozzá. Az ubiquitinnel 7, E3 ubiquitin protein ligase jelölt fehérje ezután lebontásra kerül. $\mathrm{Ez}$ a folyamat biztosítja a fehérjék dinamikus egyensúlyát a sejten belül.

RAD23B
RAD23 homolog B
(S. cerevisiae)

Az ubiquitinfüggő fehérje degradációja során, a poliubiquitinált fehérjék proteaszómához történő szállításában vesznek részt.

A különböző proteoszómákon (PSMC2 és PSMC1) keresztül közvetett hatása lehet az osteoblast-differenciációra és a kanonikus Wnt jelátvitelre.

A gének neveit és általános biológiai szerepük leírását a GeneCards (http:// www.genecards.org), NCBI (http://www.ncbi.nlm.nih.gov/gene) és az IPA (https://reports.ingenuity.com) adatbázisaiból gyűjtöttük. Az upstream regulátorok által szabályozott elemek listáját az IPA-elemzés eredményei adták. A csontanyagcseréhez köthető biológiai szerepüket a felsorolt adatbázisokból és a szakirodalomból gyújtöttük.

[26] szerepe lehet az osteoblast-differenciációban. A Gm11225 (3-hydroxyisobutyrate dehydrogenase pseudogene) és AI593442 (C1lorf87, chromosome 11 open reading frame 87 ) biológiai szerepe a csontanyagcserében nem ismert.

A top kanonikus útvonalak között a két szer esetén közös volt a GABA-receptor jelátviteli útvonal. A vizsgálatok során a receptorcsalád 4 tagjának ( $G A B R Q$ GABRB1, GABRG3 és GABBR2) megnövekedett gén- expresszióját detektáltuk. Funkcionális GABA-receptorok konstitutívan jelen vannak az osteoblastokon és a mesenchymalis sejteken, amelyeknek szerepük lehet a remodeling során a sejtproliferációban és -differenciációban [27-29]. A GABA-receptorok közvetítésével az osteoblastok kulcsfontosságú differenciációs markerei, mint a csont morfogenetikus protein 2 (BMP2) és az oszteokalcin, egyaránt fokozott aktivációt mutat. Azonban az azonosított $G A B B R 2$ gátolja az alkalikusfoszfatáz-aktivitást és a kalciumakkumulációt stromasejtekben [30]. A GABRBI pedig pozitívan szabályozza a kondrogenezist. A bemutatott eredmények alapján is látszik, hogy a GABA-jelátvitel milyen sok kapcsolódási ponton érinti a csontsejtek múködését, amely útvonalat mindkét szer szignifikánsan befolyásolta.

$\mathrm{Az}$ imatinibbel kezelt sejtekben a legjelentösebben $(-\log \mathrm{p}=2,61 \mathrm{E} 00)$ a reelin jelátviteli útvonal elemeinek génexpressziója változott meg. Ez elsősorban a szinapszisok képződésében és a neurodegenerációban vesz részt. Genomszintü asszociációs vizsgálatok során (GWAS) igazolták, hogy a reelint kódoló $R E L N$ gén variánsa összefügg egy csontbetegség, az otosclerosis kialakulásával [31]. A Reelin képes a nagyon kis denzitású lipoprotein receptorához kapcsolódni (VLDLR), amely kísérletünkben a top upstream regulátorok között szerepel. Így létrehoz egy szignalizációs komplexet (Reelin/ VLDLR/ApoER2/Dabl), amelynek funkciója a csontanyagcsere vonatkozásában még nem tisztázott. Azonban az egyes molekulakomponenseit kódoló gének szignifikánsan megnövekedett kifejeződését tapasztaltuk imatinibkezelést követően.

$\mathrm{Az}$ imatinibadagolás szignifikáns változást okozott a szerotoninreceptor jelátviteli útvonalhoz tartozó gének mRNS-expressziójában. A szerotonin (5-hidroxitriptamin, 5-HT) receptorok számos típusa megtalálható a csontsejteken, mint az 5-HTl és 5-HT2 receptorok [32-35]. Vizsgálatunkban azonban a szerotoninreceptorok ettól eltéró, 5-ös csoportjába tartozó 5-HT5A receptort kódoló HTR $5 A$ gén upregulálódását mértük. Irodalmi adatok alapján a szerotonin szabályozó szerepet tölt be a csontrendszerben. Ha szintézise a periférián történik, akkor hormonként viselkedik és gátolja a csontépítést. Ezzel szemben, ha a központi idegrendszerben szintetizálódik, akkor neurotranszmitterként viselkedve erős pozitív hatást fejt ki a csonttömegre, elősegíti a csontépítést és visszaszorítja a reszorpciót. A szerotonerg hatás pontos direkt vagy indirekt mechanizmusa a csont metabolikus folyamataiban napjainkig még részleteiben nem felderített.

Nilotinib hatására a legerőteljesebb változást $(-\log \mathrm{p}=$ 5,27E00) az EIF2 jelátviteli útvonal mutatta. Az EIF2 (eukaryotainiciációs faktor 2) GTP-kötő fehérjeként szabályozza, illetve elindítja a transzlációt. Nem megfelelő múködése megváltoztathatja a sejt fehérjekészletének szintézisét és a sejtek túlélését (https://reports.ingenuity.com). Emellett elősegíti az előalakokból történő osteoblast-differenciációt irányító, aktiváló transzkripciós 
faktor 4 (AFT4) átíródását [36-38]. A foszforilált eIF2 $\alpha$ és downstream regulátorai részt vesznek az osteoblastok vírusfertőzés vagy tápanyaghiány miatt kialakuló endoplazmás reticulum stresszválaszában, amelyek módosítják a csontátépülés aktivitását [36-38].

A nilotinib hatására megváltozó $N A N O G$ homeobox gén az IPA szoftveres analízis alapján több szabályozási útvonal kulcseleme (Embrionális össejt-differenciáció szivsejtvonal irányba, Az embrionális össejtek transzkripciót szabályozó hálózata, Oct4 szerepe az emlós embrionális össejt pluripotenciában). A gén a primer csontvelői mesenchymalis őssejtek csontsejt irányú elköteleződését és a csontszöveti regenerációt vezérli. Továbbá összeköttetést biztosít a csont morfogenetikus protein (BMP) kaszkáddal.

Előzetes alapkutatási eredményeink limitációja, hogy csak egy sejtkultúrán végeztük el a tirozinkináz-gátló kezeléseket. További vizsgálatok szükségesek a bemutatott génexpressziós eredmények és útvonal-analízisek megerősítéséhez, valós idejü RT-PCR alapú validálásához és funkcionális teszteléséhez. A biológiailag is jelentős célmolekulák sejtszintü szabályozómechanizmusainak mélyebb feltérképezéséhez pedig további sejtvonalakon végzett vizsgálatok megvalósítását tervezzük.

Összefoglalásként elmondhatjuk, hogy elsőként készítettünk a hazai szakirodalomban hiánypótló, átfogó irodalmi áttekintést a tirozinkináz-gátlók csontanyagcserét befolyásoló hatásaival kapcsolatban, és végeztünk teljes transztkriptomanalízist osteoblast-kultúrán a sejtszintú hatásmechanizmus jobb megértését szolgálva. Az imatinib- és nilotinibkezelések hatására az osteoblast-sejtvonalon tapasztalt génexpressziós mintázatbeli változások alátámaszthatják a korábbi in vivo csontanyagcserét érintő klinikai megfigyeléseket.

Anyagi támogatás: A közlemény megírása, illetve a kutatómunka anyagi támogatásban nem részesült.

Szerzői munkamegosztás: L. P., T. I., K. J. P., N. Zs.: A tanulmány alapjául szolgáló kísérletek megtervezése és koordinálása. L. G., H. P., Á. K., T. B., K. A., K. Gy.: A kísérletekben való részvétel és adatelemzés. K. Gy. Szakirodalom kutatása, feldolgozása, a kézirat megfogalmazása. L. P., B. B.: A kézirat tartalmának átvizsgálása. A cikk végeleges változatát valamennyi szerző elolvasta és jóváhagyta.

Érdekeltségek: A szerzőknek nincsenek érdekeltségeik.

\section{Irodalom}

[1] Cohen, M. H., Moses, M. L., Pazdur, R.: Gleevec ${ }^{\mathrm{TM}}$ for the treatment of chronic myelogenous leukemia: U.S. Food and Drug Administration regulatory mechanisms, accelerated approval, and orphan drug status. Oncologist, 2002, 7(5), 390-392.

[2] Jönsson, S., Hjorth-Hansen, H., Olsson, B., et al.: Imatinib inhibits proliferation of human mesenchymal stem cells and promotes early but not late osteoblast differentiation in vitro. J. Bone Min er. Metab., 2012, 30(1), 119-123.

[3] Benito, R., Lumbreras, E., Abáigar, M., et al.: Imatinib therapy of chronic myeloid leukemia restores the expression levels of key genes for DNA damage and cell-cycle progression. Pharmacogenet. Genomics, 2012, 22(5), 381-388.

[4] Vandyke, K., Fitter, S., Dewar, A. L., et al.: Dysregulation of bone remodeling by imatinib mesylate. Blood, 2010, 115(4), 766774.

[5] O'Sullivan, S., Lin, J. M., Watson, M., et al.: The skeletal effects of the tyrosine kinase inhibitor nilotinib. Bone, 2011, 49(2), 281-289.

[6] O'Sullivan, S., Naot, D., Callon, K., et al.: Imatinib promotes osteoblast differentiation by inhibiting PDGFR signaling and inhibits osteoclastogenesis by both direct and stromal cell-dependent mechanisms. J. Bone Miner. Res., 2007, 22(11), 1679-1689.

[7] Wiblidal, P., Karlic, H., Pfeilstöcker, M., et al.: Imatinib mesylate (IM)-induced growth inhibition is associated with production of spliced osteocalcin - mRNA in cell lines. Leuk. Res., 2008, $32(3), 437-443$.

[8] Tibullo, D., Giallongo, C., La Cava, P., et al.: Effects of imatinib mesylate in osteoblastogenesis. Exp. Hematol., 2009, 37(4), 461-468.

[9] Fitter, S., Dewar, A. L., Kostakis, P., et al.: Long-term imatinib therapy promotes bone formation in CML patients. Blood, 2008, $111(5), 2538-2547$.

[10] Fierro, F., Illmer, T., Jing, D., et al.: Inhibition of platelet-derived growth factor receptor beta by imatinib mesylate suppresses proliferation and alters differentiation of human mesenchymal stem cells in vitro. Cell Prolif., 2007, 40(3), 355-366.

[11] Vandyke, K., Fitter, S., Drew, J., et al.: Prospective histomorphometric and DXA evaluation of bone remodeling in imatinibtreated CML patients: Evidence for site-specific skeletal effects. J. Clin. Endocrinol. Metab., 2013, 98(1), 67-76.

[12] Berman, E., Girotra, M., Cheng, C., et al.: Effect of long term imatinib on bone in adults with chronic myelogenous leukemia and gastrointestinal stromal tumors. Leuk. Res., 2013, 37(7), 790-794.

[13] Berman, E., Nicolaides, M., Maki, R. G., et al.: Altered bone and mineral metabolism in patients receiving imatinib mesylate. $\mathrm{N}$. Engl. J. Med., 2006, 354(19), 2006-2013.

[14] Tibullo, D., Barbagallo, I., Giallongo, C., et al.: Effects of secondgeneration tyrosine kinase inhibitors towards osteogenic differentiation of human mesenchymal cells of healthy donors. Hematol. Oncol., 2012, 30(1), 27-33.

[15] Jönsson, S., Olsson, B., Ohlsson, C., et al.: Increased cortical bone mineralization in imatinib treated patients with chronic myelogenous leukemia. Haematologica, 2008, 93(7), 1101-1103.

[16] O'Sullivan, S., Horne, A., Wattie, D., et al.: Decreased bone turnover despite persistent secondary hyperparathyroidism during prolonged treatment with imatinib. J. Clin. Endocrinol. Metab., 2009, 94(4), 1131-1136.

[17] Lawrence, L.: Long-term treatment with imatinib affected bone mineral density. Cancer Network, 2013.

[18] Chen, H., Kolman, K., Lanciloti, N., et al.: P53 and MDM2 are involved in the regulation of osteocalcin gene expression. Exp. Cell Res., 2012, 318(8), 867-876.

[19] Chim, S. M., Qin, A., Tickner, J., et al.: EGFL6 promotes endothelial cell migration and angiogenesis through the activation of extracellular signal-regulated kinase. J. Biol. Chem., 2011, 286(25), 22035-22046.

[20] Green, J., Nusse, R., van Amerongen, R.: The role of Ryk and Ror receptor tyrosine kinases in Wnt signal transduction. Cold Spring Harb. Perspect. Biol., 2014, 6(2), a009175.

[21] Cho, H. Ү., Jung, J. Ү., Park, H., et al.: In vivo deletion of CAR resulted in high bone mass phenotypes in male mice. J. Cell. Physiol., 2014, 229(5), 561-571. 
[22] Li, W. F., Hou, S. X., Үu, B., et al.: Genetics of osteoporosis: perspectives for personalized medicine. Per. Med., 2010, 7(6), 655668.

[23] Deleting Mef2c in mice increases bone mass. Bonekey Rep., $2012,1,61$.

[24] Lotinun, S., Pearsall, R. S., Horne, W. C., et al.: Activin receptor signaling: A potential therapeutic target for osteoporosis. Curr. Mol. Pharmacol., 2012, 5(2), 195-204.

[25] Bab, I., Smoum, R., Bradshaw, H., et al.: Skeletal lipidomics: regulation of bone metabolism by fatty acid amide family. Br. J. Pharmacol., 2011, 163(7), 1441-1446.

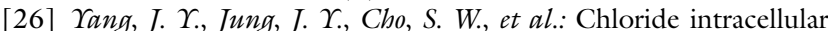
channel 1 regulates osteoblast differentiation. Bone, 2009, 45(6), 1175-1185.

[27] Muhammad, S. I., Maznah, I., Mahmud, R., et al.: Upregulation of genes related to bone formation by gamma-amino butyric acid and gamma-oryzanol in germinated brown rice is via the activation of GABA(B)-receptors and reduction of serum IL- 6 in rats. Clin. Interv. Aging, 2013, 8, 1259-1271.

[28] Fujimori, S., Hinoi, E., Yoneda, Y.: Functional GABA(B) receptors expressed in cultured calvarial osteoblasts. Biochem. Biophys. Res. Commun., 2002, 293(5), 1445-1452.

[29] Takahata, Y., Takarada, T., Hinoi, E., et al.: Osteoblastic $\gamma$-aminobutyric acid, type B receptors negatively regulate osteoblastogenesis toward disturbance of osteoclastogenesis mediated by receptor activator of nuclear factor $\kappa \mathrm{B}$ ligand in mouse bone. J. Biol. Chem., 2011, 286(38), 32906-32917.

[30] Mentink, A., Hulsman, M., Groen, N., et al.: Predicting the therapeutic efficacy of MSC in bone tissue engineering using the molecular marker CADMl. Biomaterials, 2013, 34(19), 45924601 .

[31] Schrauwen, I., Ealy, M., Huentelman, M. J., et al.: A Genomewide analysis identifies genetic variants in the RELN gene associ- ated with otosclerosis. Am. J. Hum. Genet., 2009, 84(3), 328338.

[32] Westbroek, I., van der Plas, A., de Rooij, K. E., et al.: Expression of serotonin receptors in bone. J. Biol. Chem., 2001, 276(31), 28961-28968.

[33] Bliziotes, M. M., Eshleman, A. J., Zhang, X. W., et al.: Neurotransmitter action in osteoblasts: expression of a functional system for serotonin receptor activation and reuptake. Bone, 2001, 29(5), 477-486.

[34] Dai, S. Q., Yu, L. P., Shi, X., et al.: Serotonin regulates osteoblast proliferation and function in vitro. Braz. J. Med. Biol. Res., 2014, 47(9), 759-765.

[35] Yadav, V. K., Ducy, P., Karsenty, G.: Serotonin: a new player in the regulation of bone remodeling. Medicographia, 2010, 32(4), 357-363.

[36] Saito, A., Ochiai, K., Kondo, S., et al.: Endoplasmic reticulum stress response mediated by the PERK-eIF2 alpha-ATF4 pathway is involved in osteoblast differentiation induced by BMP2. J. Biol. Chem., 2011, 286(6), 4809-4818.

[37] Hamamura, K., Yokota, H.: Stress to endoplasmic reticulum of mouse osteoblasts induces apoptosis and transcriptional activation for bone remodeling. FEBS Lett., 2007, 581(9), 17691774.

[38] Hirasawa, H., Jiang, C., Zhang, P., et al.: Mechanical stimulation suppresses phosphorylation of eIF2 alpha and PERK-mediated responses to stress to the endoplasmic reticulum. FEBS Lett., $2010,584(4), 745-752$.

(Kirschner Gyöngyi, Budapest, Korányi S. u. 2/A, 1083 e-mail: pontlike@gmail.com)

\section{A rendezvények és kongresszusok híranyagának leadása}

a lap megjelenése előtt legalább 40 nappal lehetséges, a 6 hetes nyomdai átfutás miatt. Kérjük megrendelőink szíves megértését.

A híranyagokat a következő címre kérjük: Orvosi Hetilap titkársága: Budai.Edit@akkrt.hu Akadémiai Kiadó Zrt. 